\title{
Impact evaluation of the Vila Viçosa small hydroelectric power plant (Portugal) on the water quality and on the dynamics of the benthic macroinvertebrate communities of the Ardena river
}

\author{
T. Jesus ${ }^{1}$, N. Formigo 2 , P. Santos ${ }^{2} \&$ G. R. Tavares ${ }^{3}$ \\ ${ }^{1}$ Universidade Fernando Pessoa; Rua da Constituição, 56 5, 4200-191 Porto; Teleph: + 35122 5503929, E- \\ mail: tmjesus@sapo.pt ou tjesus@ufp.pt \\ ${ }^{2}$ Departamento de Zoologia-Antropologia, Faculdade de Ciências da Universidade do Porto - Praça Gomes \\ Teixeira s/n, 4099-002 Porto, Teleph: + 351223101499 Fax: 351223101511 \\ ${ }^{3}$ Escola Secundária de Arouca. Comenda - Rossas, 4540-486 arouca. E-mail: comenda@mail.pt
}

\begin{abstract}
Over a two-year period a study of the Vila Viçosa small hydroelectric development, located on the Ardena river (hydrographical basin of the Douro river, Portugal), was conducted, with the objective of evaluating the impact of its operation on the water quality and on the dynamics of the benthic macroinvertebrate community. A morphological, hydrologic and physico-chemical characterization of the system was done, an analysis of the benthic macroinvertebrate communities looking into their structure and dynamics, as well as ecological and physiological characteristics.

With the physical and chemical data, a study of its spatial and temporal variation was performed. With the data related to the macroinvertebrate communities, an analysis of the spatial variation of some indexes and metrics and of the (non) similarity between the samples collected were done, bearing in mind the composition of the communities, through different techniques of multivariate analysis.

After the analysis of the data, it is possible to say that the Ardena River is a lothic system, with good water quality, in which the working of the small hydroelectric power plant causes alterations on the macroinvertebrate community, due to the alteration of the "natural" hydrologic regime. The impact on the macroinvertebrate communities is lower upstream of the plant, where the flow is minimal throughout the whole year leading to a change in the structure of the community. Downstream of the plant, where the flow is extremely variable, there is an impoverishment of the communities, leading to the displacement of substrate and organisms.
\end{abstract}

Keywords: environmental impact, small hydroelectric power plant, macroinvertebrates, water quality

\section{RESUMEN}

Durante dos años se ha estudiado la minicentral hidroeléctrica de Vila Viçosa en el río Ardena (cuenca del Duero, Portugal), con el objetivo de evaluar el impacto de su funcionamiento en la calidad del agua y en la dinámica de la comunidad de macroinvertebrados bentónicos, haciendo la caracterización del sistema desde el punto de vista morfológico, hidrológico y físico-químico y estudiando las comunidades de macroinvertebrados bentónicos, atendiendo a aspectos relacionados con su estructura, dinámica y características ecológicas y fisiológicas.

Con los datos relativos a los parámetros físico-químicos se ha hecho el estudio de la variación espacio temporal; y con los datos relativos a la comunidad de macroinvertebrados, se ha hecho el estudio de la variación espacial de algunos índices y medidas y de la (dis)similaridad entre las muestras recogidas, teniendo en cuenta su composición, a través de diferentes técnicas de análisis multivariante.

Después de analizados los datos, se puede decir que el río Ardena es un sistema lotico con agua de buena calidad y que el funcionamiento de la minicentral hidroeléctrica provoca modificaciones en la comunidad de macroinvertebrados bentónicos, resultado de las alteraciones de caudales. El impacto en las comunidades de macroinvertebrados es menor aguas arriba de las minicentrales, donde el caudal es mínimo todo el año provocando una modificación en la estructura de las comunidades. Aguas abajo de las minicentrales, donde el caudal es muy variable, hay un empobrecimiento de las comunidades, provocando el desplazamiento del substrato y de los organismos.

Palabras clave: impacto ambiental, minicentrales hidroeléctricas, macroinvertebrados, calidad del agua 


\section{INTRODUCTION}

In the last years in Portugal, and since the publication of the law decree 189/88 which created incentives to the production of hydroelectric energy in small hydroelectric developments (installed power less then 10MVA) (APMH, 1997), there was a big increase in the building of this kind of enterprises, mainly in the water courses north of the Mondego river (Costa, 1997).

Although in comparison with other forms of the electrical energy production (nuclear or thermal centrals and large barrages) this kind of exploitation may be considered as an environment-friendly one (Costa, 1997; Monteiro, 1996), what really happens is that the operation of the hydroelectric power plant causes some problems in the water courses. These problems are primarily related to the alteration of the "natural" hydrological regime and the alteration of the abiotic conditions of the systems, with the consequent changing of the structure and dynamics of the biotic communities. Therefore, it is becoming increasingly important to proceed to the characterization and quantification of these problems (Herrmann \& Sahlén, 1999; Kefford \& Lake, 1999).
In this work, that is part the doctoral thesis "Small hydroelectric developments: impact on the benthic macro invertebrate communities dynamics and on the water quality variability (small hydroelectric power plant of Vila Viçosa and "Alva waterfall")" (Jesús, 2001), a study of the Vila Viçosa small hydroelectric power plant was done. The location of this study is on the last $4 \mathrm{Km}$ of the Ardena river (Fig. 1), an affluent of the right margin of the Paiva river (hydrographic basin of the Duero river). The objectives of this study were to:

- Evaluate the impact of the operation of one small hydroelectric power plant on the physico-chemical and biological water quality;

- Evaluate the influence of the flow variations produced by the operation of the small hydroelectric power plant in the composition and structure of the benthic macro invertebrate communities;

- Verify the existence of a relation between the water physical-chemical characteristics and the benthic macro invertebrate communities' structure.

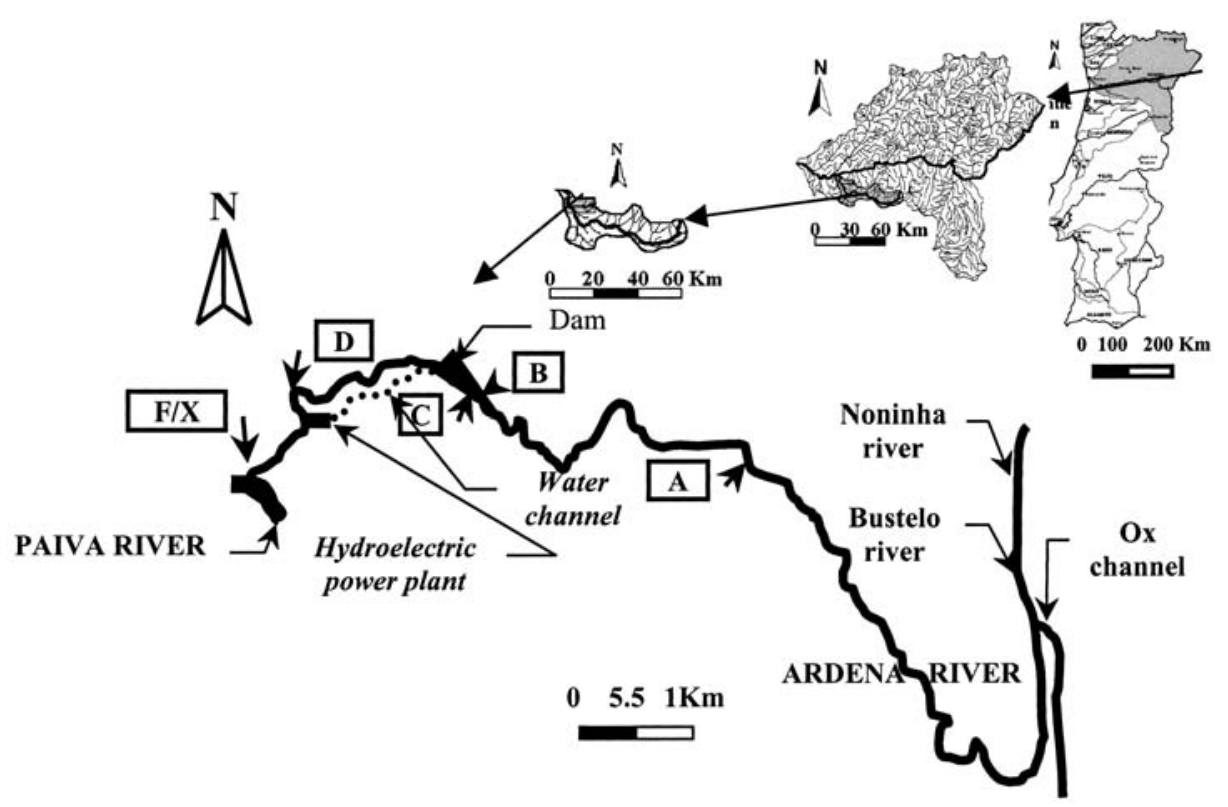

Figure 1. Sample points location on Ardena River. Localización de las estaciones de muestreo en el río Ardena. 
Table 1. Abiotic parameters analysed on the sampling points of the Ardena River, their methods, units and bibliography references. Parámetros abióticos analizados en las estaciones de muestreo del río Ardena, metodologías, unidades y referencias bibliográficas.

\begin{tabular}{|c|c|c|c|}
\hline Parameter & Method & Units & Bibliographic references \\
\hline Width and Depth & Metric & $\mathrm{m}$ & (JESUS, 2001) \\
\hline Water velocity & Distance covered by time unit & $\mathrm{m} / \mathrm{s}$ & (JESUS, 2001) \\
\hline Flow & $\begin{array}{l}\text { Calculated through the with, depth } \\
\text { and water velocity data }\end{array}$ & $\mathrm{m}^{3} / \mathrm{s}$ & (PLATTS et al., 1983) \\
\hline Canopy & $\begin{array}{l}\text { Visual observation of area of the river } \\
\text { with shadow }\end{array}$ & $\%$ & (JESUS, 2001) \\
\hline Substrate & $\begin{array}{l}\text { Visual observation of the proportion of each } \\
\text { substrate component: mud, silt, gravel, } \\
\text { pebbles, stones and macrophits }\end{array}$ & $\%$ & (JESUS, 2001) \\
\hline Air and Water temperature & With a thermometer & ${ }^{\circ} \mathrm{C}$ & APHA, 1992 \\
\hline Conductivity & $\begin{array}{l}\text { Electrometric, using an portable apparatus } \\
1 \text { HI } 933000 \text { da HANNA instruments }\end{array}$ & $\mu \mathrm{S} / \mathrm{cm}$ & APHA, 1992 \\
\hline $\mathrm{pH}$ & $\begin{array}{l}\text { Electrometry, using na portable apparatus } \\
\text { pH Meter HI } 9025 \text { da HANNA instruments }\end{array}$ & Sorensen scale & APHA, 1992 \\
\hline Alkalinity & Colorimetric method & $\mathrm{mg} \mathrm{CaCO}_{3} / 1$ & WELCH, 1948 \\
\hline Hardness & $\begin{array}{l}\text { With a titrimetric method using } \\
\text { a MERK-Aquamerk } 8047 \text { apparatus }\end{array}$ & $\mathrm{mg} \mathrm{CaCO} / 1$ & APHA, 1992 \\
\hline Dissolved Oxygen $\left(\mathrm{O}_{2}\right)$ & Winkler method & $\mathrm{mg} \mathrm{O}_{2} / 1$ & APHA, 1992 \\
\hline Biochemical & Dissolved oxygen determination by Winkler & $\mathrm{mg} \mathrm{O}_{2} / 1$ & APHA, 1992 \\
\hline Oxygen Demand $\left(\mathrm{BOD}_{5}\right)$ & $\begin{array}{l}\text { method, before and after } 5 \text { days of incubation } \\
\left(20^{\circ} \mathrm{C} \pm 1^{\circ} \mathrm{C} \text { without light }\right)\end{array}$ & & \\
\hline Ammonium $\left(\mathrm{NH}_{4}^{+}\right)$ & Colorimetric reaction & $\mathrm{mg} \mathrm{NH}_{4}^{+} / 1$ & APHA, 1992 \\
\hline $\begin{array}{l}\text { Nitrites }\left(\mathrm{NO}_{2}^{-}\right) \\
\text {Nitrates }\left(\mathrm{NO}_{3}^{-}\right) \\
\text {Phosphates }\left(\mathrm{PO}_{4}^{3-}\right)\end{array}$ & Colorimetric reaction & $\mathrm{mg} / 1$ & $\begin{array}{l}\text { STRICKLAND } \\
\& \text { PARSONS, } 1972\end{array}$ \\
\hline $\begin{array}{l}\text { Total Suspended Solids } \\
\text { (T.S.S.) }\end{array}$ & $\begin{array}{l}\text { Filtration with a membrane of } 0.4 \mathrm{~mm} \text {, } \\
\text { drying a } 105^{\circ} \mathrm{C} \text { and weight }\end{array}$ & $\mathrm{mg} / 1$ & APHA, 1992 \\
\hline
\end{tabular}

\section{MATERIALS AND METHODS}

During this study, and over a two-year period (February 1998 to January 2000), some abiotic parameters were measured monthly (Table 1) and the benthic macroinvertebrate communities were sampled every three months, along the last $6 \mathrm{~km}$ of the Ardena river.

The selection of the sampling points was made keeping in mind the localization of each element of the small hydroelectric power plant, and six sampling points were chosen as follows (Fig. 1):

- 3 reference points, situated upstream of the lagoon, where the torrent regime was as closest to "natural" as possible: point $\mathrm{A}$, about $6 \mathrm{~km}$ from the mouth of the Ardena river; point B, situated above the first dam, upstream of the lagoon, and point $\mathrm{C}$, immediately upstream of the lagoon; in conjunction with point $\mathrm{B}$. This point allowed us to verify whether the many dams that exist throughout the river caused alterations in the composition and structure of the benthic macroinvertebrate community.

- 1 point between the dam and the hydroelectric plant: point $\mathrm{D}$, where the river flow is generally low throughout the whole year.

- 2 points downstream of the hydroelectric plant discharge: point $\mathrm{E}$ and point $\mathrm{F}(\mathrm{F} / \mathrm{X})$.

The samples of the benthic macroinvertebrate community were collected with a surber 
$\left(0,09 \mathrm{~m}^{2}\right.$ area) (Campaioli et al., 1994) and as many samples as the represented mesohabitats were collected at every sampling point (Armitage et al., 1995; Armitage \& Pardo, 1995). This way, 7 sub-samples were collected in each point, representing the several mesohabitats present: mud, sand, gross sand, gravel, rolled pebbles, blocks and macrophytes. In point $F$, two sets of sub-samples were collected, designated as $\mathrm{F}$ and $\mathrm{X}$. Due to its great hydro-morphological variety there was a zone which was constantly flooded (F) and an area that was only covered by water during the discharge periods $(\mathrm{X})$ of the small hydroelectric power plant, respectively.

After being collected, the samples were conserved in formaldehyde and transported to the laboratory for a posterior washing, triage and identification of the individuals, whenever possible to the genus (Karr, 1999).

With the data relating to physico-chemical parameters a Principal Components Analysis (PCA) was made to verify the existence of some pattern of space or time variation, followed by a discriminating analysis with the samples grouped by season of the year, in order to test the existence of a seasonal distribution of the samples. Both analysis were made with the help of the STATISTICA 6.0 software, after the standardization of the data $(\mathrm{x}=(\mathrm{x}-\mathrm{x}) / \mathrm{sdx})$, in order to reduce the variability between the variables imposed by the different units in which they were determined (Clarcke \& Warwick, 1994).
With the data related to the benthic macroinvertebrate communities, a study of the spatial variation of Shannon-Weaver diversity and the Pielou equitability indexes was done (Ludwig \& Reynolds, 1988). Two biological water quality indexes were used (BMWP' - modified biological monitoring working party score system of Alba-Tercedor \& Sánchez-Ortega, 1988 and IBB - Belgian Biotic Index of De Pauw \& Vanhooren, 1983). Some metrics were also estimated (community: density, taxonomic group number, \% Ephemeroptera, Plecoptera and Tichoptera (EPT), \% of scrappers, \% of fixed organisms and $\%$ of Hydropsychidae), as well as a sample expressed in taxonomical terms (Jesus, 2001).

In order to determine how the operation of the small hydroelectric power plant altered the composition and structure of the benthic macroinvertebrate communities, a non-Multidimensional Scaling Analysis (n-MDS) was carried out. This analysis was aimed to put the samples in order, bearing in mind its taxonomic composition and the season of the year, using the Bray-Curtis similarity coefficient applied to the transformed data matrix $(x=\log (x+1))$. A similarity analysis (ANOSIM) and an analysis of the specific composition (SIMPER) were applied to the groups formed in the n-MDS, in order to verify its validity and to determine the main taxa responsible for the differentiation of the groups. For this analyses the PRIMER 5.2.2 software was used (Field et al., 1982; Clarcke \&

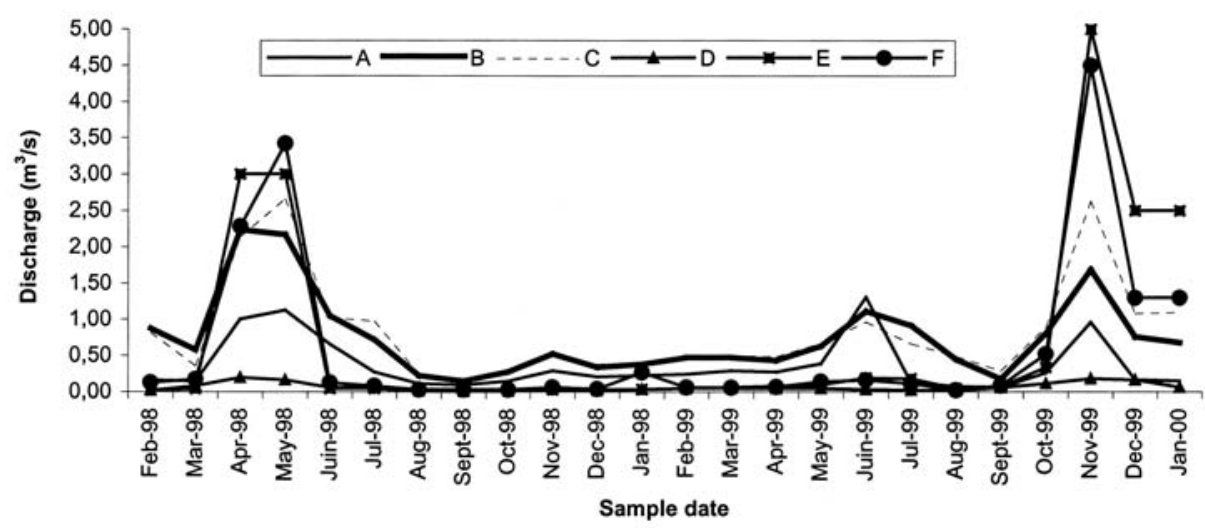

Figure 2. Temporal discharge variation in each sample point. Variación temporal de los caudales en cada estación de muestreo. 
Table 2. Main characteristics of each sampling point of the Ardena River. Principales características de cada estación de muestreo del río Ardena.

\begin{tabular}{|c|c|c|c|c|c|c|c|}
\hline \multicolumn{2}{|l|}{ Characteristics } & $\begin{array}{c}\text { Point } \\
\text { A }\end{array}$ & $\begin{array}{l}\text { Point } \\
\text { B }\end{array}$ & $\begin{array}{l}\text { Point } \\
\text { C }\end{array}$ & $\begin{array}{l}\text { Point } \\
\text { D }\end{array}$ & $\begin{array}{l}\text { Point } \\
\text { E }\end{array}$ & $\begin{array}{l}\text { Point } \\
\text { F/X }\end{array}$ \\
\hline \multicolumn{2}{|l|}{ Length (m) } & 5 & 5 & 5 & 7.5 & 5 & 5 \\
\hline \multicolumn{2}{|c|}{ Hydrologic regime } & "Natural" & "Natural" & "Natural" & Artificial & Artificial & Artificial \\
\hline \multirow{2}{*}{$\begin{array}{l}\text { Mean discharge } \\
\left(\mathrm{m}^{3} / \mathrm{s}\right)\end{array}$} & Drought season $^{(1)}$ & 0.20 & 0.43 & 0.53 & 0.04 & 0.07 & 0.12 \\
\hline & Rainy season ${ }^{(2)}$ & 1.01 & 1.65 & 1.77 & 0.16 & 3.20 & 2.60 \\
\hline \multirow{2}{*}{$\begin{array}{l}\text { With } \\
(\mathrm{m})\end{array}$} & Minimal & 7.20 & 12.60 & 5.50 & 4.10 & 6.20 & 3.50 \\
\hline & Maximal & 9.50 & 12.60 & 9.10 & 6.30 & 13.20 & 9.60 \\
\hline \multirow{2}{*}{$\begin{array}{l}\text { Maximal depth } \\
\text { (m) }\end{array}$} & Lower discharge & 0.35 & 0.35 & 0.65 & 0.55 & 0.35 & 0.30 \\
\hline & Higher discharge & 0.65 & 0.60 & 1.00 & 0.80 & 0.80 & 0.65 \\
\hline \multicolumn{2}{|l|}{ Canopy (\%) } & 95 & 0 & 15. & 50 & 30 & 80 \\
\hline \multicolumn{2}{|l|}{ AVH values } & 161 & 161 & 144 & 153 & 132 & 143 \\
\hline \multirow{2}{*}{ QBR } & Values & 90 & 65 & 60 & 100 & 55 & 85 \\
\hline & Quality class & $\begin{array}{l}\text { Good } \\
\text { quality }\end{array}$ & $\begin{array}{l}\text { Accetable } \\
\text { quality }\end{array}$ & $\begin{array}{l}\text { Accetable } \\
\text { quality }\end{array}$ & $\begin{array}{l}\text { Natural } \\
\text { stade }\end{array}$ & $\begin{array}{l}\text { Accetable } \\
\text { quality }\end{array}$ & $\begin{array}{l}\text { Good } \\
\text { quality }\end{array}$ \\
\hline
\end{tabular}

$\mathrm{AVH}$ - index of visual habitat evaluation; QBR - index of riparian vegetation quality

(1) On the sample points $\mathrm{E}$ and $\mathrm{F} / \mathrm{X}$ this value was calculated with data obtained during the time when the small electric power plant was stopped

Green, 1988; Clarcke, 1993; Clarcke et al., 1993; Clarcke \& Warwick, 1994).

The evaluation of the habitat quality was made, in situ, through the calculation of two indexes: index of quality of the riparian vegetation (QBR) (Munné et al., 1998), and visual evaluation of the habitat (AVH) (EPA, 1999), as well as the determination in percentage of the composition of the substrate in each sampling point (Jesus, 2001).

\section{Characterization of the Ardena River and sampling points}

The Ardena river is a small water course of about $19 \mathrm{Km}$ in length, which springs on the Montemuro mountain as a small brook named Noninha, which takes the name of Bustelo brook at about $3 \mathrm{~km}$ from the spring. Approximately 5 $\mathrm{km}$ from the spring there is a dam where most of it deviates into a watering channel - "the drain of the ox" - which ends on the Paiva River. It is from this place that the Ardena River is formed by the non-deviated water and by the junction of waters from superficial spilling and from small lateral water lines. Throughout its course, the Ardena river runs through a valley of a considerable slope and presents an alternation of rapids and dead waters, caused either by the natural features of the ground or by the several little dams built for the deviation of the waters to watering channels. The Vila Viçosa small hydroelectric plant is situated in the last $4 \mathrm{Km}$ of the river since 1993 (Fig. 1) (Jesus, 2001).

In the lagoon of the small hydroelectric plant, situated about $4,5 \mathrm{Km}$ from the mouth of the 


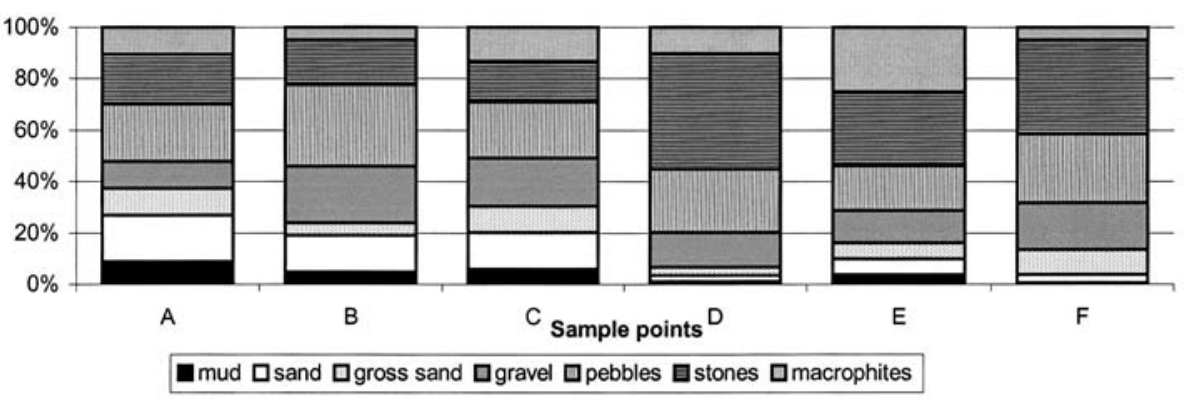

Figure 3. Substrate composition in each sample point. Composición del substrato en cada estación de muestreo.

Ardena river, the water is retained, and is afterwards deviated through a derivation channel that runs parallel to the river into the hydroelectric plant. There, after being turbinated, it returns to the original stream, about $1 \mathrm{Km}$ from the mouth. This deviation and posterior return of the water is a source of great daily fluctuations on the hydrologic regime (Fig. 2 and Table 2).

At the three reference points (A, B and C), as at the other sampling points, the substrate is composed by rocky materials of different dimensions, but without predominance of any type of materials. The aquatic vegetation is relatively scarce and limited to the riverbanks. These three points present a hydrologic regime that, according with the rainfall intensity, can be considered natural with seasonal fluctuations (Fig. 3).

In the last three sampling points $(\mathrm{D}, \mathrm{E}, \mathrm{F})$, there is a predominance of rougher materials on the river substrate that can be explained by the artificial character of the hydrologic regime. In point $\mathrm{D}$, the flow is reduced almost all the time to avoid the transportation of medium size materials. In points $\mathrm{E}$ and $\mathrm{F}$, there are periods with very strong discharges that cause the dragging of light materials.

In point $E$ the the density of the aquatic vegetation increases because there is a great percentage of the riverbed that remains dry for long periods a time and is colonized by vegetation from the margins (Fig. 3).

Every sampling point presents riparian vegetation of acceptable quality and a habitat with favourable characteristics for the development of aquatic life. This may be because the river runs through a very confined valley where human activities are still reduced, predominating the practice of subsistence agriculture and Eucalyptus forestry exploitations (Table 2).

\section{RESULTS AND DISCUSSION}

\section{Analysis of the physical-chemical parameters}

The analysis of the samples' distribution in the space defined by the two first factors of the principal components analysis $(38,8 \%$ of explained variance) shows that the presence of the small hydroelectric plant doesn't significantly influence the physical and chemical quality of the water. However, the existence of a distribution of the samples collected throughout the first factor (20,9\% of the variance) was verified, indicating a seasonal character in the variation of these parameters. This, in turn, seems explained by the natural variations of the water and air temperatures, as well as by the water flow, which reverberates in factors such as $\mathrm{pH}$, hardness, conductivity, alkalinity, and dissolved oxygen concentration (Figs. 4 and 5) (Gasith \& Resh, 1999).

The $\mathrm{pH}$, conductivity, alkalinity and hardness, present higher values during the hottest months, which can be related to the fact that in these months the flow is at its lowest, provoking an accumulation of sediments and an increase in the primary productivity (Peckarsky et al., 1990). Dissolved oxygen concentration is inversely related to temperature and directly related to the water flow, so that, the oxygen solubility 


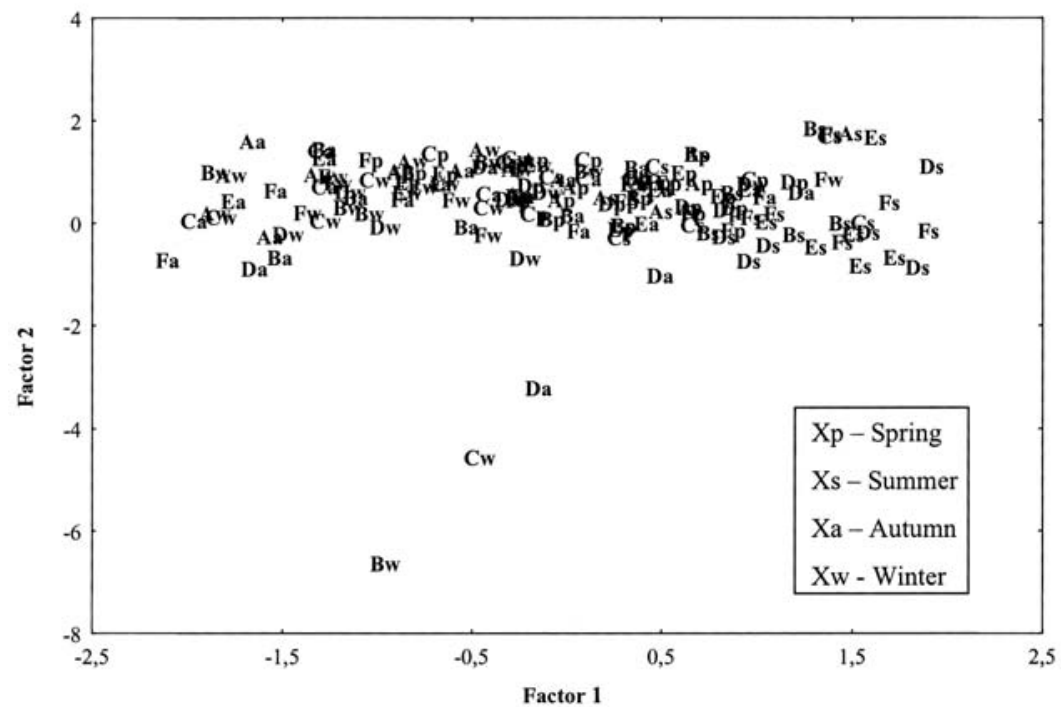

Figure 4. Sample ordination for the main physic-chemical parameters analysis in all sample points in the space formed by the two first factors of the principal components analysis (PCA) (explained variance: factor $1-20.9 \%$; factor $2-17.9 \%$ ). Ordenación de las muestras en todas las estaciones de muestreo según el análisis de los principales parámetros físico-químicos, en el espacio formado por los dos primeros factores del Análisis de Componentes Principales (PCA) (varianza explicada: factor 1-20.9\%; factor 2 - $17.9 \%$ ).

decreases with the increase in temperature. The same happens with the decrease of the flow, which reduces the turbulence of the water. In addition to these factors, we also found an increase in the metabolic rate of the aquatic

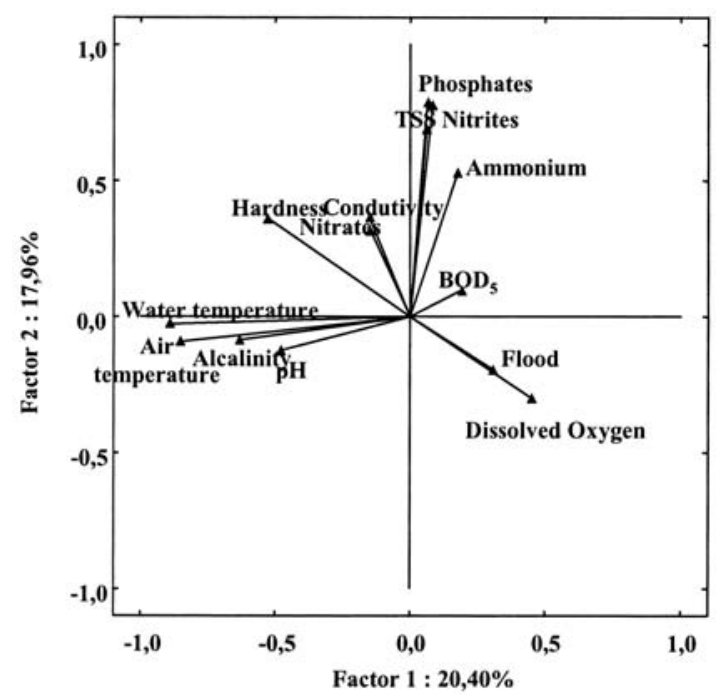

Figure 5. Representation of the correlation circle of the physical-chemical parameters determined with the two first axis of PCA. Representación del círculo de correlación de los parámetros físico-químicos determinado con los dos primeros ejes del PCA. organisms, which leads to an increase in oxygen consumption (Giller \& Malmqvist, 1998).

The discriminating analysis grouped the samples collected in the summer (July, August, and

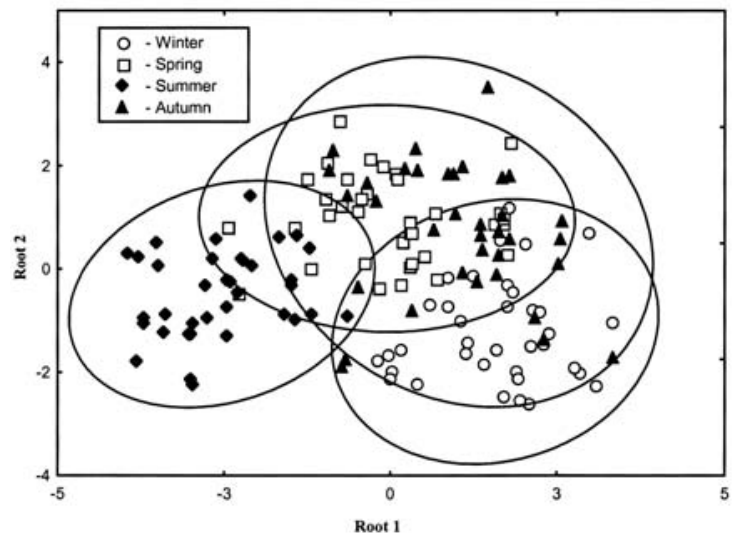

Figure 6. Graphic representation of the discriminant analysis showing the distribution of the collected samples grouped by seasons on the plane of the two principals axis (root 1 and root 2). Discriminant function: $y=-0.69$ air temperature -0.60 $\mathrm{NO}_{3}{ }^{-}-0.45$ air temperature $+0.29 \mathrm{O}_{2}+0.27 \mathrm{pH}+0.26$ conductivity $+0.22 \mathrm{NO}_{2}^{-}$. Representación gráfica del análisis discriminante mostrando la distribución de las muestras recogidas agrupadas por estaciones del año en el plano de los dos ejes principales (root 1 y root 2). Función discriminante: $y=$ -0.69 temperatura aire - $0.60 \mathrm{NO}_{3}{ }^{-}-0.45$ temperatura aire $+0.29 \mathrm{O}_{2}+0.27 \mathrm{pH}+0.26$ conductividad $+0.22 \mathrm{NO}_{2}^{-}$. 
Table 3. Average, minimum, maximum, and standard deviation of the physical-chemical parameters of each sampling point. Media, minimo, máximo y desviación estándar de los parámetros físico-químicos de cada estación de muestreo.

\begin{tabular}{|c|c|c|c|c|c|c|c|c|c|c|c|c|c|c|c|}
\hline & & 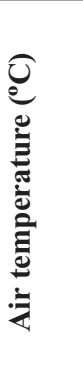 & 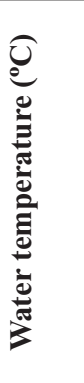 & 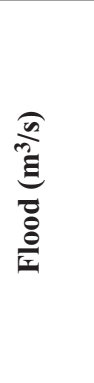 & 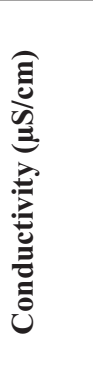 & 풀 & 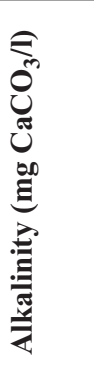 & 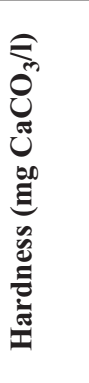 & 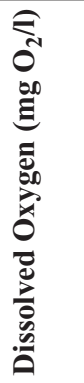 & 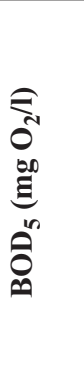 & 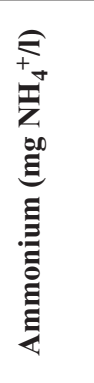 & 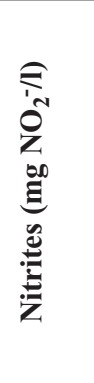 & 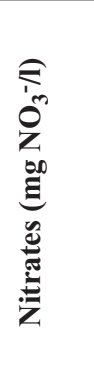 & 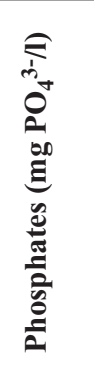 & 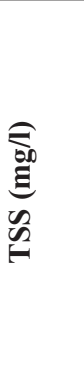 \\
\hline \multirow[t]{4}{*}{ Point A } & Max & 33.0 & 18.0 & 1.31 & 76.1 & 7.2 & 11.0 & 9.0 & 11.5 & 4.1 & 0.04 & 0.01 & 4.37 & 0.05 & 0.02 \\
\hline & Aver & 16.2 & 11.9 & 0.36 & 44.5 & 6.6 & 6.3 & 5.3 & 10.3 & 1.1 & 0.01 & 0.01 & 2.75 & 0.01 & 0.01 \\
\hline & Min & 3.0 & 5.0 & 0.06 & 22.8 & 6.0 & 3.0 & 1.0 & 8.9 & 0.1 & 0.00 & 0.00 & 1.44 & 0.00 & 0.00 \\
\hline & $\mathrm{Sdx}$ & 8.22 & 3.69 & 0.361 & 14.36 & 0.36 & 2.74 & 1.97 & 0.80 & 0.96 & 0.014 & 0.003 & 0.821 & 0.013 & 0.008 \\
\hline \multirow[t]{4}{*}{ Point B } & Max & 35.0 & 19.0 & 2.24 & 89.9 & 7.2 & 14.0 & 13.0 & 12.4 & 3.3 & 0.06 & 0.07 & 5.13 & 0.30 & 0.05 \\
\hline & Aver & 17.1 & 14.5 & 0.75 & 55.5 & 6.6 & 7.2 & 6.3 & 10.2 & 1.2 & 0.01 & 0.01 & 3.35 & 0.02 & 0.01 \\
\hline & Min & 3.0 & 6.0 & 0.15 & 30.8 & 5.9 & 3.0 & 2.0 & 8.5 & 0.1 & 0.00 & 0.00 & 1.59 & 0.00 & 0.00 \\
\hline & $\mathrm{Sdx}$ & 8.89 & 3.95 & 0.563 & 17.74 & 0.36 & 2.55 & 2.57 & 0.87 & 0.91 & 0.017 & 0.014 & 0.862 & 0.060 & 0.01 \\
\hline \multirow[t]{4}{*}{ Point $\mathrm{C}$} & Max & 35.0 & 19.0 & 2.66 & 87.1 & 7.3 & 12.0 & 11.0 & 12.5 & 3.4 & 0.03 & 0.05 & 5.13 & 0.19 & 0.06 \\
\hline & Aver & 17.3 & 12.5 & 0.84 & 56.3 & 6.6 & 7.4 & 6.0 & 10.5 & 1.2 & 0.01 & 0.01 & 3.43 & 0.02 & 0.01 \\
\hline & Min & 3.0 & 6.0 & 0.17 & 33.8 & 5.7 & 3.0 & 3.0 & 8.9 & 0.2 & 0.0 & 0.00 & 1.69 & 0.00 & 0.00 \\
\hline & $\mathrm{Sdx}$ & 9.27 & 3.99 & 0.695 & 16.44 & 0.39 & 2.51 & 1.87 & 0.91 & 0.90 & 0.008 & 0.011 & 0.855 & 0.038 & 0.013 \\
\hline \multirow[t]{4}{*}{ Point D } & Max & 32.0 & 19.5 & 0.20 & 99.2 & 7.3 & 16.0 & 13.0 & 11.8 & 3.9 & 0.05 & 0.03 & 5.22 & 0.109 & 0.06 \\
\hline & Aver & 17.0 & 12.8 & 0.07 & 72.7 & 6.6 & 9.3 & 9.3 & 10.5 & 1.1 & 0.01 & 0.01 & 3.41 & 0.03 & 0.01 \\
\hline & Min & 4.0 & 4.0 & 0.01 & 39.2 & 5.7 & 4.0 & 5.0 & 8.9 & 0.0 & 0.00 & 0.0 & 2.27 & 0.00 & 0.00 \\
\hline & $\mathrm{Sdx}$ & 8.14 & 4.52 & 0.055 & 16.18 & 0.41 & 3.06 & 2.20 & 0.96 & 1.06 & 0.012 & 0.007 & 0.843 & 0.032 & 0.014 \\
\hline \multirow[t]{4}{*}{ Point E } & Max & 34 & 20.0 & 5.00 & 97.6 & 7.1 & 15.0 & 12.0 & 12.8 & 2.8 & 0.04 & 0.01 & 5.21 & 0.07 & 0.02 \\
\hline & Aver & 17.2 & 12.7 & 0.73 & 65.4 & 6.6 & 8.8 & 8.7 & 10.4 & 0.9 & 0.01 & 0.00 & 3.45 & 0.02 & 0.01 \\
\hline & Min & 4.0 & 4.0 & 0.010 & 30.8 & 5.9 & 5.0 & 5.0 & 8.4 & 0.1 & 0.00 & 0.00 & 2.19 & 0.00 & 0.00 \\
\hline & $\mathrm{Sdx}$ & 7.80 & 4.50 & 1.369 & 20.35 & 0.32 & 2.67 & 2.18 & 1.24 & 0.68 & 0.011 & 0.002 & 0.816 & 0.019 & 0.005 \\
\hline \multirow[t]{4}{*}{ Point F } & Max & 36.0 & 20.0 & 4.50 & 98.3 & 7.5 & 16.0 & 14.0 & 13.0 & 2.9 & 0.06 & 0.03 & 4.63 & 0.04 & 0.03 \\
\hline & Aver & 18.3 & 12.8 & 0.63 & 62.7 & 6.6 & 8.54 & 8.2 & 10.5 & 1.2 & 0.01 & 0.00 & 3.44 & 0.01 & 0.01 \\
\hline & Min & 4.00 & 3.0 & 0.02 & 29.2 & 6.0 & 4.0 & 4.0 & 8.9 & 0.1 & 0.00 & 0.00 & 2.40 & 0.00 & 0.00 \\
\hline & $\mathrm{Sdx}$ & 8.77 & 4.67 & 1.173 & 20.26 & 0.41 & 2.84 & 2.36 & 1.17 & 0.88 & 0.015 & 0.007 & 0.626 & 0.014 & 0.011 \\
\hline
\end{tabular}

BOD - Biochemical Oxygen Demand; TSS - total suspended solids; Max - maximal; Min - minimal; Aver - average; Sdx - standard deviation

September) and in the winter (January, February, and March) in an opposite situation, occupying the autumn and spring samples an intermediate situation (Fig. 6). The analysis of the discriminating function makes it clear that those factors such as air, water temperature, and nitrates are the main responsible factors for the variations in the values obtained for the physical and chemical parameters.
The physical-chemical parameters analysed in this fragment of the Ardena river present values within a range, which is proper of a good water quality, with weak mineralization and low productivity. These characteristics favour the normal development of the aquatic life and even present the right conditions for the development of recreational activities (Table 3) (Nisbet \& Verneaux, 1970; Giller \& Malmqvist, 1998). 


\section{Analysis of the benthic macroinvertebrate communities}

\section{Composition and structure}

The macroinvertebrate communities found in the Ardena River are formed by a great variety of taxa where the organisms most sensitive to the abiotic factors, such as the Ephemeroptera and Trichoptera, are the most numerous (Fig. 7). They present high diversity and equitability, which may mean that the populations are more or less stable and adapted to the fluctuations of the abiotic factors. These facts can be explained by the hydromorphological characteristics of the sampling points, that present a diversified and relatively stable substrate throughout the whole water course, with several interstitial spaces which are proportionately important refuges for the process of re-colonization (Seddel et al., 1990).

The relative abundance of scrapers and of fixed individuals is uniform in every sampling point, which is due to the similar structure of its substrate and to the fact that they are individuals that are hardly dragged by a sudden increase of the flow (Hauer \& Lamberti, 1996).

\section{Spatial structural variability}

Despite this high richness and taxonomic diversity, there is a clear difference between the points situated upstream of the Vila Viçosa small hydroelectric power plant (points A, B, and C), and the points $\mathrm{D}, \mathrm{E}, \mathrm{F}$, and $\mathrm{X}$, situated downstream of the same development (Fig. 8). The points D, E, F, and $\mathrm{X}$ present a density and specific richness, which are quite lower than the other sampling points. They are characterised by a decrease in the percentage of the more sensitive organisms (Ephemeroptera, Trichoptera and Plecoptera), and an increase in the percentage of Hydropsychidae, which can explain the decrease of the biotic index values. Attending to the results obtained for the abiotic parameters, this impoverishment of the macro invertebrate communities seems to be explained by the variability of the river flow imposed by the different elements of the hydroelectric power plant (Poff \& Ward, 1989; Palmer \& Poff, 1997; Puckridge et al., 1998).

In point $\mathrm{D}$ the river flow is reduced and constant throughout almost the whole year, which allows for the homogenisation of habitat conditions and the instauration of characteristics common to lenthic systems. These can promote the replacement of individuals with more demands, in environmental terms, and adapted to waters with a higher flow speed (Plecoptera, Ephemeroptera and Trichoptera), by individuals that are characteristic of places with waters that flow slower (Heteroptera, Coleoptera and Diptera). The reduction of the density and of the species' richness can be related to the reduction

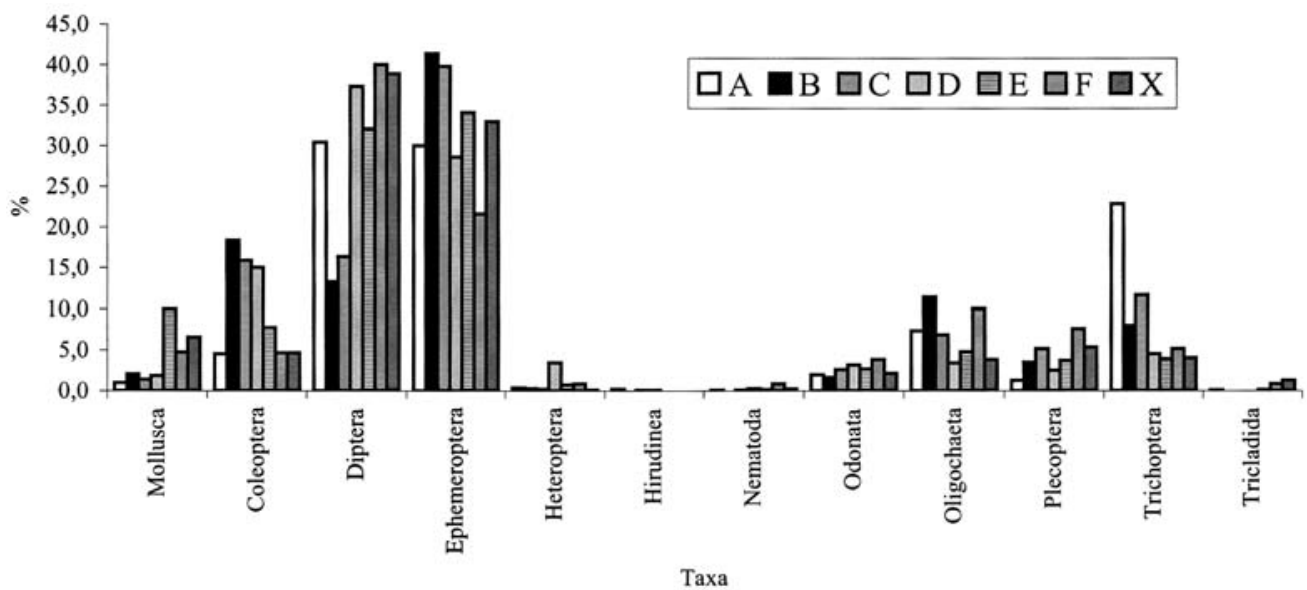

Figure 7. Average of taxonomic composition of the macro invertebrate community in each sample point. Media de la composición taxonómica de la comunidad de macroinvertebrados en cada estación de muestreo. 

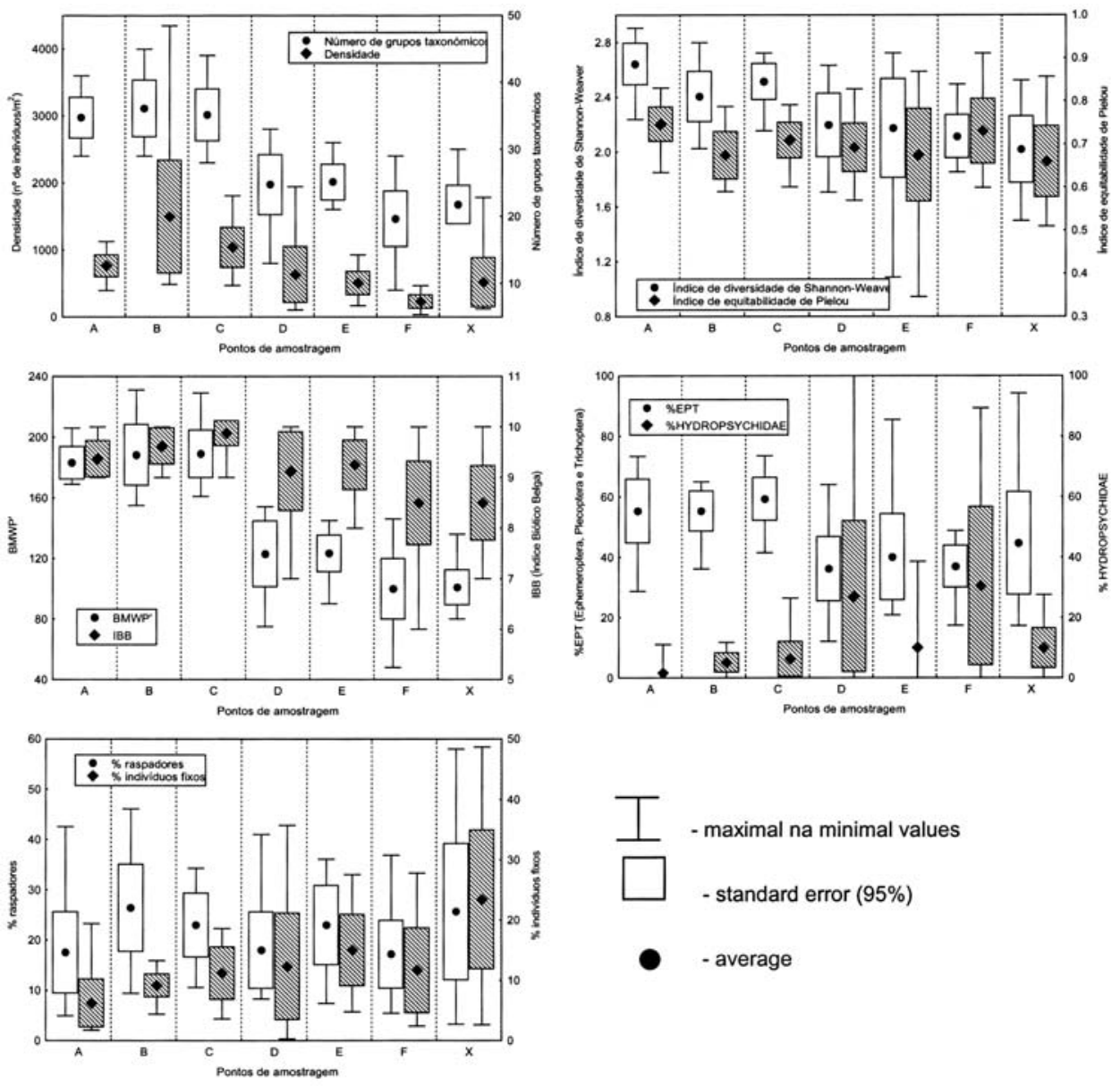

Figure 8. Graphical representation of the spatial variation of the minimal, middle, and maximal values and of the standard error of some parameters and metrics related with the benthic macroinvertebrate communities. Representación gráfica de la variación espacial de los valores mínimos, medios y máximos y del error estándar de algunos parámetros y métricos relacionados con las comunidades bentónicas de macroinvertebrados.

of the area of the habitat that is available, either due to the decrease in the quantity of water or to the accumulation of thinner sediments, which can induce competition and predation (Stanley et al., 1997; Peckarsky et al., 1990).

Points E, F, and X present a great daily and seasonal flow variation, which creates a great space and time heterogeneity of the system conditions. This variability has repercussions in the habitat structure, by movements of the materials constituting the riverbed and by the removal of the perifiton from the surface of the rocks, and the consequent dragging of the individuals. This way, the organisms that subsist are the ones that possess charac- teristics that allow them to resist the dragging such as fixation structures (suckers or hooks), living buried in the substrate (Oligochaeta and some Diptera), and highly tolerants to all kind of perturbations (Boulton et al., 1992; Cobb et al., 1992; Death \& Winterbourn, 1994; Palmer \& Poff, 1997)

The relative abundance of Hydropsychidae is indicative of the quantity of organic matter in the aquatic environment. Their presence in point $\mathrm{D}$ can be explained by the low flow of the river that leads to the deposition of organic matter. In points $\mathrm{E}, \mathrm{F}$, and $\mathrm{X}$ the moisture of water coming from the lagoon may have a higher organic matter content, even though the representatives of 
Spring

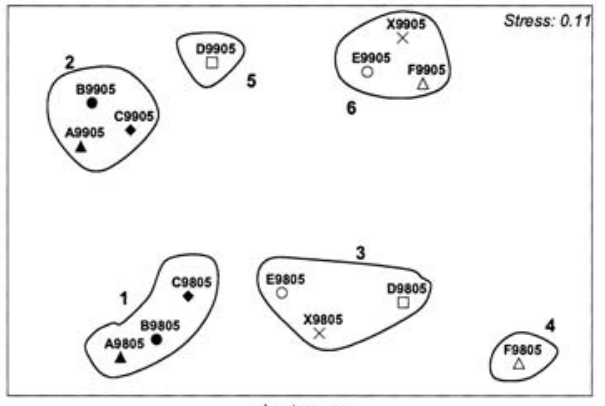

Autumn

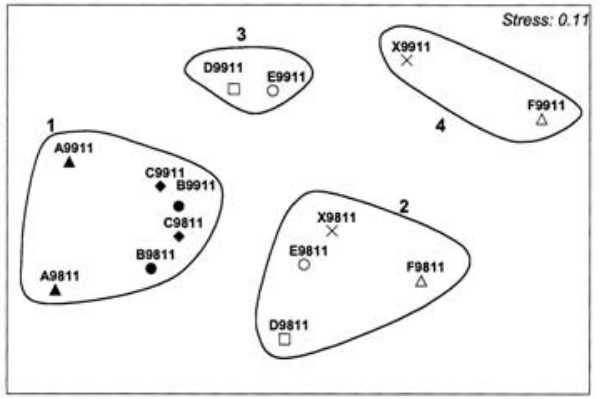

Summer

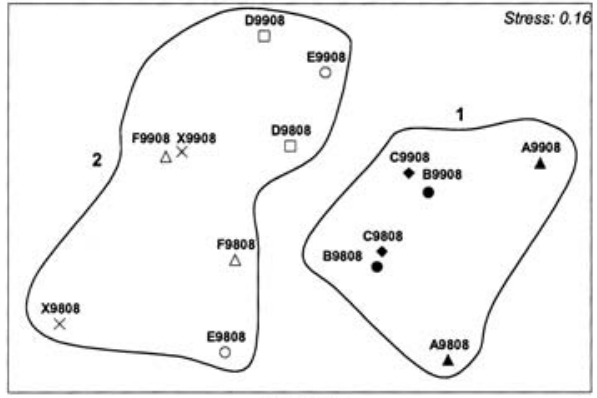

Winter

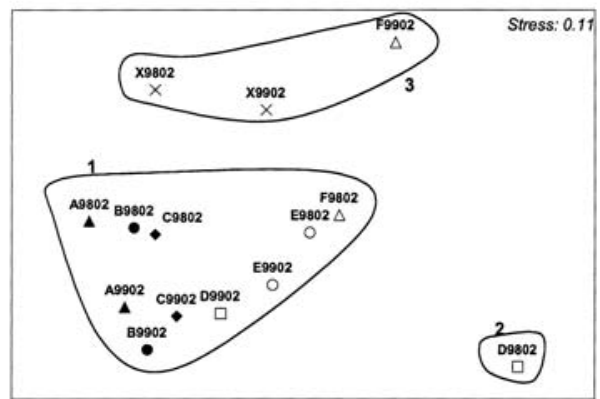

$\triangle-A \bullet-B \bullet-C \square-D \circ-E \Delta-F \times-X$

Figure 9. Sampling point ordination in each season made by the n-MDS technique with Bray-Curtys similarities between the samples, using the taxa transformed data $(\mathrm{x}=\log (\mathrm{x}+1))$. Ordenación de las estaciones de muestreo en cada estación del año realizada mediante la técnica $n-M D S$ con similaridades de Bray-Curtys entre las muestras, utilizando los datos de taxones transformados $(x=l o g(x+1))$.

this family have hooks at the tip of their abdomen that allow them to fixate themselves to the rocks. (Williams \& Feltmate, 1992; Lancaster, 1999).

\section{Spatial and temporal taxonomical composition variation}

By analysing the distribution of the samples bearing in mind its faunal composition (Fig. 9, tables 4 and 5), it is possible to see that there are significant differences between the reference points (A, $\mathrm{B}$, and C) and the other sampling points, at every season of the year. That separation becomes, however, less clear in the summer, a time in which the small hydroelectric plant ceases its function and a homogenisation of the hydrologic conditions occurs in every sampling point, allowing for their re-colonisation (Matthaei et al., 1996, 1997; Winterbottom et al., 1997).

In Spring, besides the already mentioned spatial variation evidenced by the predominance of
Chironomidae in points D, E, F, and X, (Grzybkowska, 1991), and organisms that live buried in the substrate resisting the dragging caused by the discharges of the central, there is also a difference between the samples collected in the two years. These can be due to differences in the faunal composition of the samples caused by the significant increase of the torrent that occurred in the first sampling year in every studied point due to the strong rainfall that took place.

Table 4. Values of Rglobal and its significance level obtained by the ANOSIM test, related with the similarity matrix obtained by the ordenation of figure 8. Valores de Rglobal y su nivel de significancia obtenido por el test ANOSIM, relacionado con la matriz de similitud obtenida en la ordenación de la figura 8.

\begin{tabular}{lcc}
\hline Season & Rglobal & Significance level (\%) \\
\hline Spring & 0.945 & 0.1 \\
Summer & 0.539 & 0.1 \\
Autumn & 0.886 & 0.1 \\
Winter & 0.822 & 0.1 \\
\hline
\end{tabular}


Table 5. Results of the SIMPER test related to the groups represented in figure 8. Resultados del test SIMPER relacionados con los grupos representados en la figura 8 .

\begin{tabular}{|c|c|c|c|c|}
\hline & Groups & $S_{\text {média }}(\%)$ & $D_{\text {média }}(\%)$ & Taxa (contribution to $25 \%$ ) \\
\hline \multirow[t]{21}{*}{ Spring } & 1 & 72.9 & - & Baetis, Oligochaeta, Ephemerella \\
\hline & 2 & 72.2 & - & Baetis, Oligochaeta, Orthocladiinae, Ephemerella \\
\hline & 3 & 59.0 & - & Baetis, Tanytarsini, Chironomini \\
\hline & 4 & $*$ & - & \\
\hline & 5 & $*$ & - & \\
\hline & 6 & 63.6 & - & Orthocladiinae, Leuctra \\
\hline & $1-2$ & - & 43.8 & Leuctra, Caenis, Chironomini, Ancylus, Limnephilini, Habrophlebia \\
\hline & $1-3$ & - & 42.3 & $\begin{array}{l}\text { Ephemerella, Ephemera, Simuliidae, SERICOSTOMATIDAE, } \\
\text { Tanytarsini, Ancylus, Habrophlebia, }\end{array}$ \\
\hline & $1-4$ & - & 53.3 & $\begin{array}{l}\text { Ephemera, Esolus (L), Ephemerella, SIMULIIDAE, Tanypodinae, } \\
\text { SERICOSTOMATIDAE }\end{array}$ \\
\hline & $1-5$ & - & 49.4 & Leuctra, Oxyethira, Baetis, Chironomini, Orthocladiinae, Ephemera \\
\hline & $1-6$ & - & 56.4 & $\begin{array}{l}\text { Leuctra, Baetis, Ephemera, Ephemerella, SIMULIIDAE, } \\
\text { SERICOSTOMATIDAE }\end{array}$ \\
\hline & $2-3$ & - & 52.0 & $\begin{array}{l}\text { CHIRONOMINI, Leuctra, Nemoura, Ephemera, TanytarsiniI, } \\
\text { Ephemerella }\end{array}$ \\
\hline & $2-4$ & - & 65.9 & Leuctra, Ephemera, Esolus (L), Atherix, Caenis, Ancylus \\
\hline & $2-5$ & - & 39.7 & $\begin{array}{l}\text { Ephemera, Epeorus, Nemoura, Aphelocheirus, Oligochaeta, } \\
\text { Limnephilini }\end{array}$ \\
\hline & $2-6$ & - & 49.8 & $\begin{array}{l}\text { Ephemera, Ephemerella, Limnephilini, Atherix, } \\
\text { SERICOSTOMATIDAE, Potamopyrgus, Caenis }\end{array}$ \\
\hline & $3-4$ & - & 45.4 & Tanypodinae, Chironomini, Nemoura, Ancylus, Aphelocheirus \\
\hline & $3-5$ & - & 47.0 & Chironomini, Leuctra, Oxyethira, Ephemerella, Psychomyia pusilla \\
\hline & $3-6$ & - & 47.2 & Leuctra, Chironomini, Nemoura, Potamopyrgus, Baetis \\
\hline & $4-5$ & - & 64.4 & $\begin{array}{l}\text { Leuctra, Oxyethira, Epeorus, Ephemerella, Aphelocheirus, } \\
\text { Tanypodinae }\end{array}$ \\
\hline & $4-6$ & - & 50.7 & Leuctra, Tanypodinae, Potamopyrgus, Ophiogomphus \\
\hline & $5-6$ & - & 43.3 & Ephemerella, Epeorus, SIMULIIDAE, Oxyethira, Glossosoma \\
\hline \multirow[t]{3}{*}{ Summer } & 1 & $\begin{array}{l}56.5 \\
468\end{array}$ & - & Tanypodinae, Chironomini, Orthocladiinae, Caenis, Leuctra \\
\hline & 2 & 46.8 & $-e^{0}$ & Orthocladiinae, Baetis, Polycentropus \\
\hline & $1-2$ & - & 58.8 & $\begin{array}{l}\text { Silo, Glossosoma, Chironomini, Oligochaeta, Leuctra, Caenis, } \\
\text { Tanypodinae, Limnius (L), Esolus (A) }\end{array}$ \\
\hline \multirow[t]{10}{*}{ Autumn } & 1 & 63.5 & - & Oligochaeta, SERICOSTOMATIDAE, Baetis, Atherix \\
\hline & 2 & 54.4 & - & Esolus (L), Caenis \\
\hline & 3 & 61.9 & - & Baetis, Caenis, Elmis (L) \\
\hline & 4 & 48.1 & - & Caenis, Ophiogomphus \\
\hline & $1-2$ & - & 57.2 & Ephemera, Limnephilini, SERICOSTOMATIDAE, Silo, Atherix \\
\hline & $1-3$ & - & 52.6 & $\begin{array}{l}\text { SERICOSTOMATIDAE, Ephemera, Silo, Limnephilini, Epeorus, } \\
\text { Potamopyrgus }\end{array}$ \\
\hline & $1-4$ & - & 71.2 & Oligochaeta, SERICOSTOMATIDAE, Ephemera, Limnephilini, Silo \\
\hline & $2-3$ & - & 55.5 & $\begin{array}{l}\text { SIMULIIDAE, Elmis (L), Ancylus, Potamopyrgus, Ephemerella, } \\
\text { Hydropsyche }\end{array}$ \\
\hline & $2-4$ & - & 61.3 & Oligochaeta, Ephemerella, Baetis, Esolus (L) \\
\hline & $3-4$ & - & 61.7 & Ephemerella, Oligochaeta, Hydropsyche, Elmis (L) \\
\hline \multirow[t]{6}{*}{ Winter } & 1 & 55.4 & - & Baetis, Orthocladiinae, Oligochaeta \\
\hline & 2 & $*$ & - & \\
\hline & 3 & 48.0 & - & Ephemerella, Orthocladiinae \\
\hline & $1-2$ & - & 69.5 & Baetis, Oligochaeta, Atherix, Ephemerella, SERICOSTOMATIDAE \\
\hline & $1-\overline{3}$ & - & 59.1 & $\begin{array}{l}\text { Esolus (L), Caenis, Baetis, SIMULIIDAE, SERICOSTOMATIDAE, } \\
\text { Oligochaeta }\end{array}$ \\
\hline & $2-3$ & - & 74.3 & Caenis, Ophiogomphus, Ephemerella, SIMULIIDAE \\
\hline
\end{tabular}

$\mathrm{S}_{\text {average }}$ - average similarity; $\mathrm{D}_{\text {average }}$ - average dissimilarity; * - groups with a single saple 
The difference in flow that occurred in the two sampling years is reflected in the presence of a greater abundance of Baetis and Habrophlebia, relative to the remaining types of Ephemeroptera, which are swimmer forms (Table 5). This kind of locomotion allows them to move rapidly to places with lower flow, like the marginal zones, and by the appearance of a greater quantity of organisms that live buried in the substrate (Chironomini) (Statzner et al., 1997; Townsend et al., 1997).

In the Summer we can only distinguish two groups: one (group 1) constituted by the samples of the reference points (points A, B, and C); another group (group 2) constituted by the samples of the points D, E, F, and X influenced by the operation of the small hydroelectric plant. This difference is caused by the presence of a fewer number of individuals in group 2 and by the absence of more sensitive organisms to the changes in the environmental factors, such as Trichoptera, Leuctra, Caenis, Ephemerella and Ecdyonurus (Statzner et al., 1994; Millan et al., 1997).

In the autumn, as in the spring, the occurrence of a great flow difference in the two sampling years is reflected in the composition of the benthic macroinvertebrate communities, particularly in the more sensitive points (points D, E, F, and $\mathrm{X}$ ). In the first sampling year, the river flow was reduced in every sampling point, except in points $\mathrm{E}, \mathrm{F}$, and $\mathrm{X}$ during the discharge periods (about 4 hours a day). In the second year, due to the strong waterfall, a sudden rise in the water flow occurred, which lead to the small hydroelectric development to work full time, as well as water discharges through the flood discharge. These facts can explain the low faunal diversity and density, which justify the inclusion of the samples collected in these points in the second collecting year, in separate groups. The diversity reduction is due to the elimination of individuals which do not possess forms of fixation (Esolus, Trichoptera with no cocoon), or which were dragged with the substrate (Ancylus).

In winter, and summer, in every sampling point except point $\mathrm{D}$, there is a greater identity of the hydrological regime in every sampling point, because the river flow is stronger, due to the higher rainfall of these seasons of the year. This has an effect on the composition of the macroinvertebrate communities of each sampling point. It is to be noted that in the first year the samples collected in points $\mathrm{X}$ and $\mathrm{D}$ are not included in the same group (group 2). The $X$ point sample is highly correlated to the samples collected in points $\mathrm{F}$ and $\mathrm{X}$ in the second sampling year. The differences between samples included in groups 1 and 2 are essentially due to a reduction of the effective numbers within each taxonomic group, in group 2 relatively to group 1 , which can be related with the greater persistence and pressure intensity caused by the torrent increase (Jesus, 2001).

\section{CONCLUSIONS}

The Vila Viçosa small hydroelectric power plant is situated in a place subjected to low human pressure, with little altered margins. The Ardena River is a course of water that presents a diversified and stable substrate, without a clear predominance of any kind of constituent in particular, good water quality with low mineralization and productivity and no apparent pollution,that allows the maintenance and development of aquatic life. The benthic macroinvertebrate communities are complex, stable and balanced, presenting a high richness, diversity and equitability.

The impact of the operation of the small hydroelectric power plant is felt in a different way in the fragments situated between the barrage and the central discharge and in the fragments situated downstream of them.In both cases, however, there is a decrease of the water quality and an alteration of the structure and composition of the benthic macroinvertebrate community.

It is also possible to conclude that despite the long time standing of the hydroelectric enterprise, the studied system presents conditions that favour the development of well-structured biotic communities throughout the fragments of river under study. This is supported by the fact that in the aestival period, with the suspension of the 
operations of the small hydroelectric plant, there is an almost total recovery of the communities. The abiotic factors that seem to have more importance in the distribution of the individuals are the water temperature, the dissolved oxygen concentration, the torrent speed, and the structure of the riverbed substrate.

\section{BIBLIOGRAPHY}

ALBA-TERCEDOR, J. \& A. SANCHÉZ-ORTEGA. 1988. Un método rápido y simple para evaluar la calidad biologica de las águas corrientes basado en el de Hellawell (1978). Limnetica, 4: 51-56

APHA.1992. Standard Méthods for the Examination of Water and Wastewater. $18^{\circ}$ ed.

APMH. 1997. Rendibilidade de um pequeno aproveitamento hidroeléctrico nas actuais condições de mercado. Simpósio sobre Aproveitamentos Hidroeléctricos.1997, Lisboa.

ARMITAGE, P. D. \& I. PARDO. 1995. Impact assessment of regulation at the reach level using macroinvertebrate information from mesohabitats. Regulated Rivers: Research \& Management, 10: 147-158

ARMITAGE, P. D., I. PARDO. \& A. BROWN. 1995. Temporal constance of fauna assemblages in "mesohabitats". Application to management? Archiv. Hydrobiol., 133: 67-387

BOULTON, A. J., C. G. PETERSON, N. B. GRIMM, \& S. G. FISHER. 1992. Stability of an aquatic macroinvertebrate community in a multiyear hidrologic disturbance regime. Ecology, 73: 2192-2207

CAMPAIOLI, S., P. F. GHETTI, A. MINELLI \& S. RUFFO. 1994. Manuale per il riconoscimento dei Macroinvertebrati delle acque dolci italiane, Vol.I. Provincia Autonoma di Trento. 357 pp

CLARCKE, K. R. 1993. Non-parametric multivariate analyses of changes in community structure. Aust. J. Ecol., 18: 117-143

CLARCKE, K. R. \& R. H. GREEN. 1988. Statistical design and analysis for a "biologist effects" study. Mar. Ecol. Prog. Ser., 46: 213-226

CLARCKE, K. R., R. M. WARWICK, \& B. E. BROWN. 1993. An index showing breakdown of seriation related to disturbance, in a coral-reef assemblage. Nar. Ecol. Prog. Ser., 102: 153-160

CLARCKE, K. R. \& R. M. WARWICK. 1994. Change in marine communities: an approach to statistical analysis and interpretation. Plymouth Marine Laboratory, UK

COBB, D. G., T. D. GALLOWAY, \& J. F. FLANNAGAN. 1992. Effects of discharge and substrate stability on density and species composition of stream insects. Can. J. Fish. Aquat. Sci., 49: 17881795

COSTA, A. S. 1997. Mini-hídricas em Portugal: passado, presente e fúturo. Simpósio sobre "Aproveitamentos Hidroeléctricos". 1977. Lisboa, Portugal.

DE PAUW, N. \& G. VANHOOREN. 1983. Method for biological quality assessment of watercourses in belgium. Hydrobiologia, 100: 153-168

DEATH, R. G. \& M. J. WINTERBOURN. 1994. Environmental stability and community persistence: a multivariate perspective. J. North Am. Benthol. Soc., 13: 125-139

EPA. 1999. Rapid bioassessment protocols for use in streams and wadeable rivers: periphyton, benthic macroinvertebrates and fish. $2^{\text {nd }}$ ed. United Status. 5.1- 533 pp, 7.1734 pp.

FIELD, J. G., K. R. CLARCKE, \& R. M. WARWICK. 1982. A practical strategy for analysing multispecies distribution patterns. Mar. Ecol. Prog. Ser., 8: 37-52

GASITH, A \& V. H. RESH. 1999. Streams in mediterranean climate regions. Abiotic influences and biotic responses to predictable seasonal events. Annu. Rev. Ecol. Syst., 30: 51-81

GILLER, K. W. \& B. MALMQVIST. 1998. The biology of streams and rivers. Oxford University Press, England, 296 pp

GRZYBKOWSKA, M. 1991. Development and habitat selection of CHIRONOMIDAE communities. Regulated Rivers: Research \& Management, 6: 257-264

HAUER, F. R. \& G. A. LAMBERTI. 1996. Methods in stream ecology. Academic Perss. 674 pp.

HERRMANN, J. \& C. SAHLÉN. 1999. Stream invertebrate communities responding seasonal droughts. Abstracts Book of the Symposium on Assessing the Ecological integrity of running waters. 1999. Vienna, Austria: 34.

JESUS, T. 2001. Centrais hidroeléctricas de pequena dimensão: impacto na dinâmica da comunidade de macroinvertebrados bentónicos e na variação da qualidade da água (Mini-hídrica de Vila Viçosa e "Cascata" do Alva). Dissertação de doutoramento apresentado à Faculdade de Ciências da Universidade do Porto. 235 pp 
KARR, J. R. 1999. Defining and measuring river health. Freshwat. Biol., 41: 221-234

KEFFORD, B. J. \& P. S. LAKE. 1999. Effects of spatialand temporal changes in water velocityon the density of the freshwater snail Potamopyrgus antipodarum (Gray). Molluscan Research, 20(1): 11-16

LANCASTER, J. 1999. Small-scale movements of lotic macroinvertebrates with variations in flow. Freshwat. Biol., 41: 605-619

LUDWIG, J. A. \& J.F. REYNOLDS. 1988. Statistical Ecology. A primer on methods and computing. John Wiley \& Sons, Inc. $337 \mathrm{pp}$

MATTHAEI, C. D., U. UEHLINGER, E. I. MEYER \& A. FRUTIGER. 1996. Recolonization of benthic invertebrates after experimental disturbance in a Swiss prealpine river. Freshwat. Biol., 35: 233-244

MATTHAEI, C. D., D. WERTHMULLER \& A. FRUTIGER. 1997. Invertebrate recovery from a bed-moving spate: the role of drift versus movements inside and over substratum. Archiv Hydrobiol., 140: 221-235

MILLAN A., J. L. MORENO \& J. VELASCO. 1997. Coleópteros y Heterópteros acuáticos del complejo lagunar del río Arquillo (Albacete). Separata de Albacete. Revista de estudios albacetenses, 40: 1-69

MONTEIRO, T. J. 1996. Incidências ambientais dos aproveitamentos hidroeléctricos. Ingenium, 10: 68-73

MUNNÉ, A., C. SOLÁ \& N. PRAT. 1998. QBR: Un índice rápido para la evaluación de la calidad de los ecossitemas de ribera. Tecnologia del Agua, 175: 20-37

NISBET, M. \& J. VERNEAUX. 1970. Composantes chimiques des eaux courantes - discoussion et proposition de classes en tant que bases d'interpretation des analyses chimiques. Annls. Limnol., 6(2): 161-190

PALMER, M. A. \& N. L. POFF. 1997. The influence of environmental heterogeneity on patterns and processes in stream. J. North Am. Benthol. Soc., 16: $169-173$

PECKARSKY, B. L., S. C. HORN \& B. STATZNER. 1990. Stonefly predation along a hydraulic gra- dient: a field test of the harsh-benign hypothesis. Freshwat. Biol., 24: 181-191

PLATTS, W. S., W. F. MEGAHAN \& G. W. MINSHALL. 1983. Methods for evaluating stream, riparian and biotic conditions. USDA. 1-33.

POFF, N. L. \& J. V. WARD. 1989. Implications of streamflow variability and predictability for lotic community structure: a regional analysis of streamflow patterns. Can. J. Fish.Aquat. Sci., 46: 1805-1818

PUCKRIDGE, J. T., K. F. SHELDON, K. F. WALKER \& A. J. BOULTON. 1998. Flow variability and ecology of large rivers. Marine and Freshwater Research, 49: 55-72

SEDELL, J. R., G. H. REEVES, F. R. HAUER, J. A. STANFORD \& C. P. HAWKINS. 1990. Role of refuge in recovery from disturbances: modern fragmented and disconnected river systems. Environmental Management, 14: 711-724

STANLEY, E. H., S. G. FISHER \& N.B. GRIMM. 1997. Ecosystem expansions and contraction in streams. BioScience, 47: 427-435

STATZNER, B., K. HOPPENHAUS, M.F. ARENS \& P. RICHOUX. 1997. Reproductive traits, habitat use and templet theory: a synthesis of world-wide data on aquatic insects. Freshwat. Biol., 38: 109-135

STATZNER, B., V.H. RESH \& S. DOLÉDEC. 1994. Ecology of the Upper Rhône River: a test of habitat templet theories. Freshwat. Biol., 31: 253-556

STRICKLAND, J. D. H. \& T. R. PARSONS. 1972. A practical handbook of seawater analysis. Fish. Res. Bd. Can., 167 (2nd ed.): $311 \mathrm{pp}$

TOWNSEND, C. R., S. DOLÉDEC \& M..R. SARSBROOK. 1997. Species traits in relation to temporal and spatial heterogeneity in streams: a test of habitat templet theory. Freshwat. Biol., 37: 367-387

WELCH, P.S. 1948. Limnological methods. McGraw-Hill Internat. Ed. 381 pp

WILLIAMS, D. D. \& B. W. FELTMATE. 1992. Aquatic insects. C. A. B. Internacional. 358 pp.

WINTERBOTTOM, J. H., S. E. ORTON, A. G. HILDREW \& J. LANCASTER. 1997. Field experiments on flow refugia in streams. Freshwat. Biol., 37: 569-580. 
